\title{
Centile values for serum lipids and blood pressure for Asian Indian adolescents

\author{
Malini Madhavan ${ }^{1}$, Ravindra M Pandey ${ }^{2}$, Anoop Misra*1, Naval K Vikram¹, \\ Vibha Dhingra ${ }^{1}$, Kalpana Luthra ${ }^{3}$ and Jasjeet $S$ Wasir ${ }^{1}$
}

\author{
Address: ${ }^{1}$ Department of Medicine, All India Institute of Medical Sciences New Delhi-110029, India, ${ }^{2}$ Department of Biostatistics, All India \\ Institute of Medical Sciences New Delhi-110029, India and ${ }^{3}$ Department of Biochemistry, All India Institute of Medical Sciences New Delhi- \\ 110029, India \\ Email: Malini Madhavan - malini_madhavan@yahoo.co.in; Ravindra M Pandey - rmpandey@yahoo.com; \\ Anoop Misra* - anoopmisra@metabolicresearchindia.com; Naval K Vikram - navalvikram@metabolicresearchindia.com; \\ Vibha Dhingra - vibhadhingra@yahoo.co.in; Kalpana Luthra - kalpanaluthra@hotmail.com; \\ Jasjeet S Wasir - jasjeet@metabolicresearchindia.com \\ * Corresponding author
}

Published: 29 September 2005

Lipids in Health and Disease 2005, 4:20 doi:10.1 I86/I476-5IIX-4-20

This article is available from: http://www.lipidworld.com/content/4/I/20

(C) 2005 Madhavan et al; licensee BioMed Central Ltd.

This is an Open Access article distributed under the terms of the Creative Commons Attribution License (http://creativecommons.org/licenses/by/2.0), which permits unrestricted use, distribution, and reproduction in any medium, provided the original work is properly cited.
Received: 0 I September 2005

Accepted: 29 September 2005

\begin{abstract}
Background: Reference data for plasma lipids and blood pressure are not available for Asian Indian adolescents. This study aimed to develop representative age- and sex- specific percentile reference data for serum lipids [total cholesterol (TC), triglycerides (TG), low density lipoprotein cholesterol (LDL-C), high density lipoprotein cholesterol (HDL-C), non-HDL cholesterol] and blood pressure for urban Asian Indian adolescents aged 14-18 years. The sample consisted of 680 boys and 52I girls aged 14-18 years from the cross-sectional population survey, Epidemiological Study of Adolescents and Young Adults (ESAY) for whom the data for serum lipid levels and blood pressure were recorded. Smoothed age- and sex- specific $5^{\text {th }}, 10^{\text {th }}, 25^{\text {th }}, 50^{\text {th }}, 75^{\text {th }}, 85^{\text {th }}, 90^{\text {th }}$ and $95^{\text {th }}$ percentiles where derived using LMS regression.
\end{abstract}

Results: Percentile-based reference data for serum lipids and blood pressure are presented for adolescent Asian Indian boys and girls for the first time. Asian Indian adolescents had lower levels of serum TC, LDL-C and HDL-C and higher TG than their counterparts in the USA. Interesting trends in TC and HDL-C levels where observed, which might reflect changes in dietary pattern and physical activity in this age group in India.

Conclusion: These reference data could be used to identify adolescents with an elevated risk of developing dyslipidemia, hypertension and cardiovascular disorders, to plan and implement preventive policies, and to study temporal trends.

\section{Introduction}

Atherosclerosis begins in childhood and progresses to coronary heart disease (CHD) in adults [1]. Aortic fatty streaks and fibrous plaques occur in children and adolescents [2-4]. The risk factors for atherosclerosis, such as dyslipidemia, hypertension, and insulin resistance may 
Table I: Mean (SD) of lipid levels and blood pressure in urban Asian Indian adolescents I4-I8 y of age

\begin{tabular}{|c|c|c|c|c|c|c|c|c|c|c|c|c|c|c|}
\hline \multirow[t]{2}{*}{ Age (y) } & \multicolumn{2}{|c|}{$n$} & \multicolumn{2}{|c|}{$T C(m g / d l)$} & \multicolumn{2}{|c|}{$L D L-C(m g / d l)$} & \multicolumn{2}{|c|}{$T G(m g / d l)$} & \multicolumn{2}{|c|}{ HDL-C (mg/dl) } & \multicolumn{2}{|c|}{ SBP $(m m H g)$} & \multicolumn{2}{|c|}{$\mathrm{DBP}(\mathrm{mmHg})$} \\
\hline & Boys & Girls & Boys & Girls & Boys & Girls & Boys & Girls & Boys & Girls & Boys & Girls & Boys & Girls \\
\hline 14 & 58 & 65 & $\begin{array}{l}148.9 \\
(21.0)\end{array}$ & $\begin{array}{l}148.4 \\
(26.0)\end{array}$ & $\begin{array}{l}83.8 \\
(20.3)\end{array}$ & $\begin{array}{l}80.7 \\
(26.5)\end{array}$ & $\begin{array}{l}92.4 \\
(37.8)\end{array}$ & $\begin{array}{l}95.8 \\
(28.5)\end{array}$ & $\begin{array}{l}46.5 \\
(8.5)\end{array}$ & $\begin{array}{l}48.2 \\
(10.3)\end{array}$ & $\begin{array}{l}113.9 \\
(10.3)\end{array}$ & $\begin{array}{l}111.6 \\
(9.6)\end{array}$ & $\begin{array}{l}72.6 \\
(7.6)\end{array}$ & $\begin{array}{l}72.0 \\
(7.0)\end{array}$ \\
\hline 15 & 134 & 109 & $\begin{array}{l}148.9 \\
(27.3)\end{array}$ & $\begin{array}{l}155.4 \\
(23.6)\end{array}$ & $\begin{array}{l}84.2 \\
(27.3)\end{array}$ & $\begin{array}{l}87.8 \\
(23.9)\end{array}$ & $\begin{array}{l}86.7 \\
(30.5)\end{array}$ & $\begin{array}{l}92.0 \\
(28.0)\end{array}$ & $\begin{array}{l}47.4 \\
(7.9)\end{array}$ & $\begin{array}{l}48.3 \\
(8.3)\end{array}$ & $\begin{array}{l}112.7 \\
(9.8)\end{array}$ & $\begin{array}{l}111.7 \\
(8.9)\end{array}$ & $\begin{array}{l}73.4 \\
(7.4)\end{array}$ & $\begin{array}{l}73.2 \\
(7.0)\end{array}$ \\
\hline 16 & 218 & 155 & $\begin{array}{l}149.3 \\
(24.0)\end{array}$ & $\begin{array}{l}153.8 \\
(21.4)\end{array}$ & $\begin{array}{l}82.1 \\
(25.8)\end{array}$ & $\begin{array}{l}86.4 \\
(23.2)\end{array}$ & $\begin{array}{l}89.0 \\
(29.7)\end{array}$ & $\begin{array}{l}96.7 \\
(28.0)\end{array}$ & $\begin{array}{l}47.9 \\
(6.1)\end{array}$ & $\begin{array}{l}48.0 \\
(8.5)\end{array}$ & $\begin{array}{l}I 14.1 \\
(9.5)\end{array}$ & $\begin{array}{l}111.6 \\
(9.3)\end{array}$ & $\begin{array}{l}73.9 \\
(7.0)\end{array}$ & $\begin{array}{l}72.8 \\
(6.6)\end{array}$ \\
\hline 17 & 182 & 84 & $\begin{array}{l}142.3 \\
(27.9)\end{array}$ & $\begin{array}{l}152.3 \\
(21.4)\end{array}$ & $\begin{array}{l}77.8 \\
(27.9)\end{array}$ & $\begin{array}{l}83.2 \\
(24.7)\end{array}$ & $\begin{array}{l}86.3 \\
(32.1)\end{array}$ & $\begin{array}{l}92.7 \\
(29.0)\end{array}$ & $\begin{array}{l}48.2 \\
(6.9)\end{array}$ & $\begin{array}{l}49.5 \\
(7.8)\end{array}$ & $\begin{array}{l}115.6 \\
(9.2)\end{array}$ & $\begin{array}{l}109.7 \\
(9.9)\end{array}$ & $\begin{array}{l}75.6 \\
(6.4)\end{array}$ & $\begin{array}{l}71.3 \\
(7.3)\end{array}$ \\
\hline 18 & 88 & 108 & $\begin{array}{l}136.9 \\
(24.1)\end{array}$ & $\begin{array}{l}158.1 \\
(23.8)\end{array}$ & $\begin{array}{l}71.7 \\
(22.1)\end{array}$ & $\begin{array}{l}84.3 \\
(24.7)\end{array}$ & $\begin{array}{l}89.1 \\
(34.0)\end{array}$ & $\begin{array}{l}92.3 \\
(28.9)\end{array}$ & $\begin{array}{l}47.7 \\
(7.0)\end{array}$ & $\begin{array}{l}55.6 \\
(7.6)\end{array}$ & $\begin{array}{l}116.0 \\
(9.0)\end{array}$ & $\begin{array}{l}109.8 \\
(8.2)\end{array}$ & $\begin{array}{l}75.5 \\
(6.7)\end{array}$ & $\begin{array}{l}72.5 \\
(7.2)\end{array}$ \\
\hline
\end{tabular}

TC, Total cholesterol; LDL-C, Low-density lipoprotein cholesterol; TG, Triglycerides; HDL-C, High-density lipoprotein cholesterol; SBP, Systolic blood pressure; DBP, Diastolic blood pressure.

For conversion to $\mathrm{mmol} / \mathrm{L}$ for TC, LDL-C and HDL-C, multiply by 0.02586

For conversion to $\mathrm{mmol} / \mathrm{L}$ for TG, multiply by 0.01129

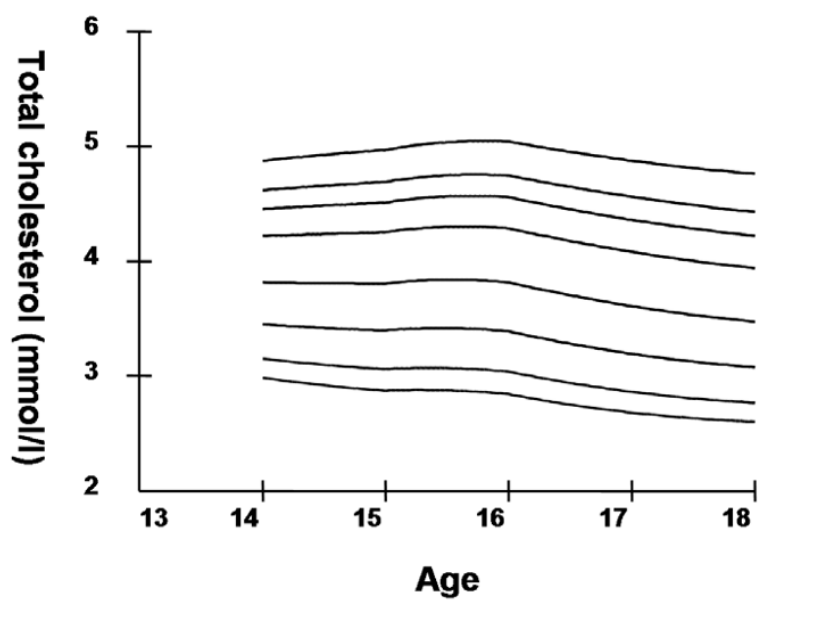

Figure I

Smoothed percentile curves for the $5^{\text {th }}$, $10^{\text {th }}, 25^{\text {th }}, 5^{\text {th }}, 7^{\text {th }}$, $85^{\text {th }}, 90^{\text {th }}$ and $95^{\text {th }}$ percentiles of total cholesterol for urban boys 14-18 years of age.

arise in children and adolescents, and contribute significantly to the acceleration of atherosclerosis [1].

Tracking of total cholesterol (TC) and low-density lipoprotein cholesterol (LDL-C) levels from childhood to adults is well known. The National Cholesterol Education Program, Adult Treatment Panel III (NCEP, ATP III) identified LDL-C as the primary target for cholesterol-lowering therapy [5]. Elevated triglycerides (TG) and low levels of

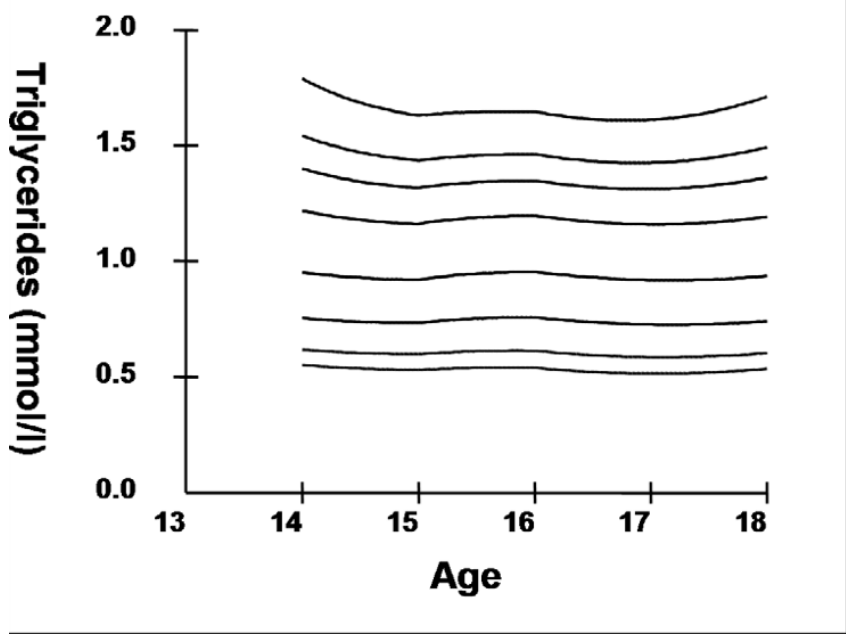

Figure 2

Smoothed percentile curves for the $5^{\text {th }}, 10^{\text {th }}, 25^{\text {th }}, 50^{\text {th }}, 7^{\text {th }}$, $85^{\text {th }}, 90^{\text {th }}$ and $95^{\text {th }}$ percentiles of serum triglycerides for urban boys 14-18 years of age.

high-density lipoprotein cholesterol (HDL-C) are markers of atherogenic dyslipidemia [6-8]. Specifically, low levels of HDL-C is an independent risk factor for CHD [9]. NonHDL cholesterol also shows strong correlation with CHD mortality [10] and has been recommended as a secondary target of therapy [5].

CHD is increasingly becoming a leading cause of death in India and other developing Asian countries. South Asians 


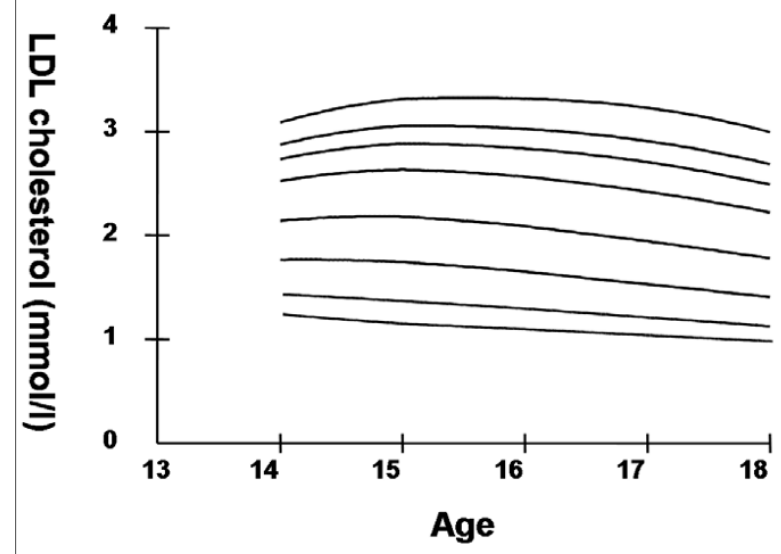

Figure 3

Smoothed percentile curves for the $5^{\text {th }}, 10^{\text {th }}, 25^{\text {th }}, 50^{\text {th }}, 75^{\text {th }}$, $85^{\text {th }}, 90^{\text {th }}$ and $95^{\text {th }}$ percentiles of low-density lipoprotein cholesterol for urban boys 14-18 years of age.

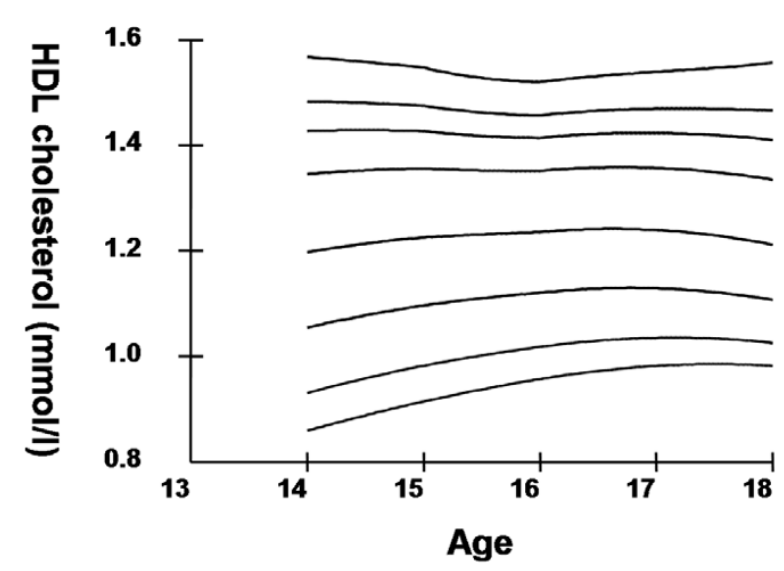

Figure 4

Smoothed percentile curves for the $5^{\text {th }}, 10^{\text {th }}, 25^{\text {th }}, 50^{\text {th }}, 75^{\text {th }}$, $85^{\text {th }}, 90^{\text {th }}$ and $95^{\text {th }}$ percentiles of high-density lipoprotein cholesterol for urban boys 14-18 years of age.

have premature and severe CHD as compared to white Caucasians [11]. Important contributory factors for CHD in South Asians are insulin resistance and resultant dyslipidemia [12]. We have recently reported that insulin resistance and low levels of HDL-C are common in Asian Indian adolescents, portending high risk for development of CHD in adults $[13,14]$.

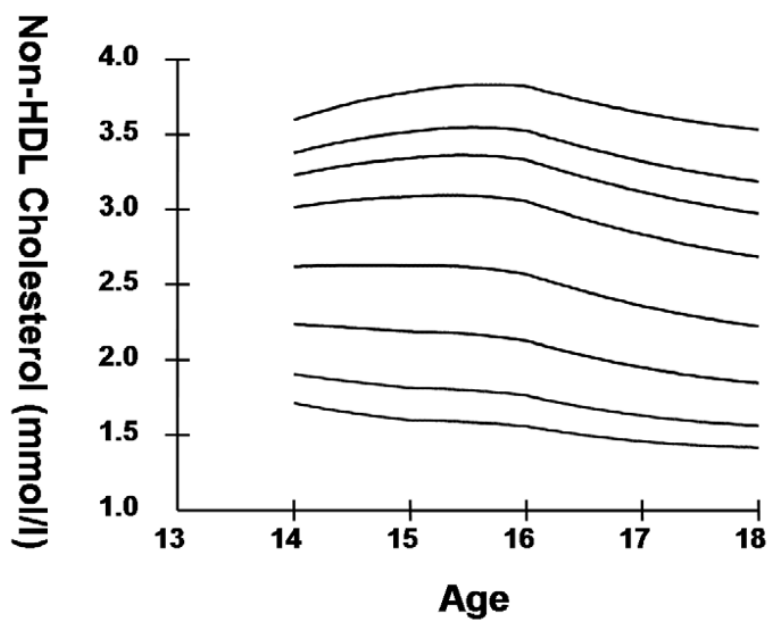

Figure 5

Smoothed percentile curves for the $5^{\text {th }}, 10^{\text {th }}, 25^{\text {th }}, 50^{\text {th }}, 7^{\text {th }}$, $85^{\text {th }}, 90^{\text {th }}$ and $95^{\text {th }}$ percentiles of non high-density lipoprotein cholesterol for urban boys 14-18 years of age.

No representative percentiles reference data for plasma lipids and blood pressure in Asian Indian adolescents are currently available. These data are required for proper diagnosis and prevention of dyslipidemia, hypertension, and CHD. The purpose of this study was to develop representative age- and sex- specific percentile reference data for serum lipids (TC, LDL-C, HDL-C, TG, non-HDL cholesterol), and blood pressure [systolic blood pressure (SBP) and diastolic blood pressure (DBP)] for urban Asian Indian adolescents aged 14-18 years (y).

\section{Methods \\ Subjects}

The data were taken from an epidemiological study involving adolescents and young adults (aged 14-25 y) from schools and colleges located in southwest area of New Delhi. Multistage cluster sampling based on modified World Health Organization Expanded Program of Immunization Sampling Plan was used to collect a representative sample of adolescents and young adults [15]. First, two separate lists, one containing the names of schools and the other containing the names of colleges located in the defined area were prepared. A 'cluster' was defined as a school or a college. A total of 40 clusters were randomly selected from the two lists. The number of schools and colleges was determined based on the proportional allocation to ensure the representativeness of the sample with respect to clusters and socioeconomic strata. For both schools and colleges, a 'section' was con- 


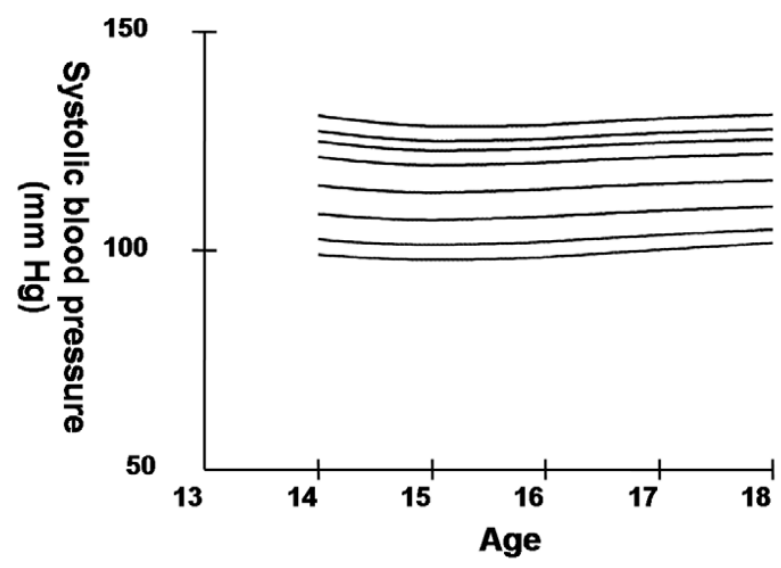

\section{Figure 6}

Smoothed percentile curves for the $5^{\text {th }}, 10^{\text {th }}, 25^{\text {th }}, 50^{\text {th }}, 7^{\text {th }}$, $85^{\text {th }}, 90^{\text {th }}$ and $95^{\text {th }}$ percentiles of systolic blood pressure for urban boys 14-18 years of age.

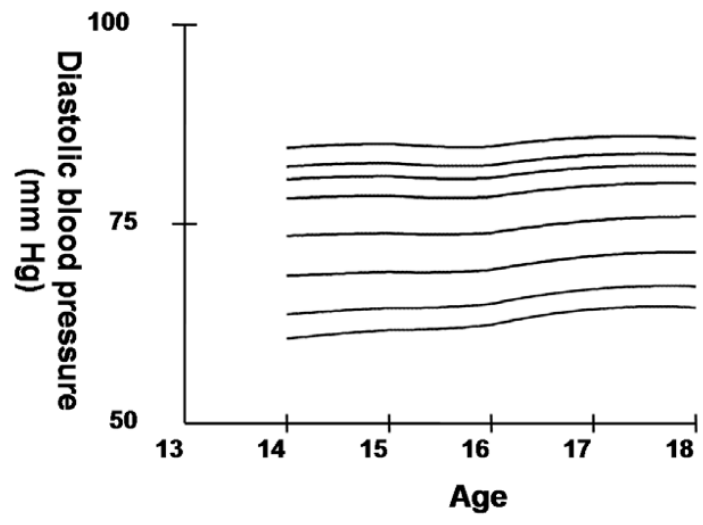

Figure 7

Smoothed percentile curves for the $5^{\text {th }}, 10^{\text {th }}, 25^{\text {th }}, 50^{\text {th }}, 75^{\text {th }}$, $85^{\text {th }}, 90^{\text {th }}$ and $95^{\text {th }}$ percentiles of diastolic blood pressure for urban boys 14-18 years of age.

sidered as the primary sampling unit at the second stage of sampling. Subsequently from each of the schools/colleges, two to four sections were selected depending upon the number of the students in the section. All the students in the selected section were included in the study. Informed consent was obtained from the parents of the selected children. The institutional ethics committee approved the study. The data set consists of 680 boys and

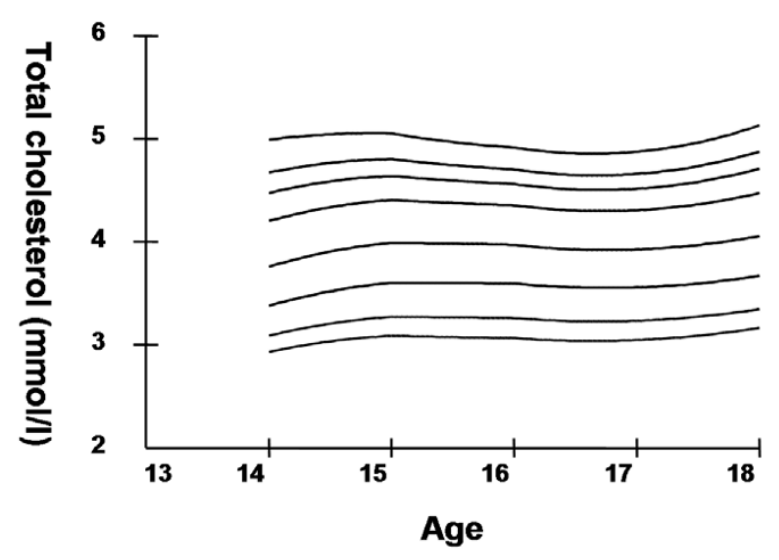

Figure 8

Smoothed percentile curves for the $5^{\text {th }}, 10^{\text {th }}, 25^{\text {th }}, 50^{\text {th }}, 75^{\text {th }}$, $85^{\text {th }}, 90^{\text {th }}$ and $95^{\text {th }}$ percentiles of total cholesterol for urban girls 14-18 years of age.

521 girls aged 14 to $18 \mathrm{y}$. The sample characteristics are presented in table 1.

\section{Lipoproteins}

For estimation of lipoproteins, blood samples were obtained after an overnight fast of 10 hours. Levels of TC, TG, and HDL-C were estimated using commercially available kits (Randox Laboratory, San Francisco, CA, USA) on a semi-automated analyzer (das srl, palombara, Sabina, Italy) as described previously $[13,16]$. Value of LDL-C was calculated according to the Friedewald's equation [17]. The estimation of all lipids was rigorously quality controlled by a consultant biochemist (KL), and frequently checked with values of another reference laboratory. Interassay and intra-assay variability of estimations were kept at less than $5 \%$.

\section{Blood Pressure}

Blood pressure was measured by a standard mercury sphygmomanometer (Industrial Electronic and Allied Products, Pune, India), after the subject had rested for 5 min in the sitting position, using the appropriate cuff size. Phase 5 Korotkoff sounds were taken for diastolic blood pressure categorization. In case of an abnormal blood pressure recording, another reading was obtained after 5 min rest and the mean of the two values was taken for the final record. The same physician measured the blood pressure using the same instrument for all the subjects. The mercury sphygmomanometer was periodically validated against a Hawksley Random Zero Sphygmomanometer (Hawksley, Lancing, Sussex, UK). 
Table 2: Smoothed age- and sex- specific serum total cholesterol (mmol/l) percentile values for urban Asian Indian adolescents 14-18 y of age.

\begin{tabular}{rllllllll}
\hline Age & $5^{\text {th }}$ & $10^{\text {th }}$ & $25^{\text {th }}$ & $50^{\text {th }}$ & $75^{\text {th }}$ & $85^{\text {th }}$ & $90^{\text {th }}$ & $95^{\text {th }}$ \\
\hline Boys & & & & & & & & \\
14 & 2.98 & 3.15 & 3.45 & 3.82 & 4.22 & 4.45 & 4.62 & 4.88 \\
15 & 2.87 & 3.06 & 3.40 & 3.81 & 4.25 & 4.51 & 4.69 & 4.97 \\
16 & 2.84 & 3.04 & 3.39 & 3.82 & 4.29 & 4.56 & 4.75 & 5.04 \\
17 & 2.68 & 2.86 & 3.19 & 3.61 & 4.08 & 4.36 & 4.56 & 4.88 \\
18 & 2.60 & 2.77 & 3.08 & 3.47 & 3.94 & 4.22 & 4.43 & 4.76 \\
Girls & & & & & & & & \\
14 & 2.93 & 3.09 & 3.38 & 3.76 & 4.20 & 4.47 & 4.67 & 4.99 \\
15 & 3.09 & 3.27 & 3.60 & 3.99 & 4.40 & 4.64 & 4.80 & 5.05 \\
16 & 3.07 & 3.26 & 3.59 & 3.97 & 4.35 & 4.56 & 4.70 & 4.91 \\
17 & 3.05 & 3.23 & 3.56 & 3.93 & 4.31 & 4.51 & 4.66 & 4.87 \\
18 & 3.16 & 3.35 & 3.67 & 4.05 & 4.47 & 4.71 & 4.88 & 5.13
\end{tabular}

Table 3: Smoothed age- and sex- specific percentile values for low-density lipoprotein cholesterol ( $\mathrm{mmol} / \mathrm{l})$ for urban Asian Indian adolescents 14-18 y of age.

\begin{tabular}{rllllllll}
\hline Age & $5^{\text {th }}$ & $10^{\text {th }}$ & $2^{\text {th }}$ & $50^{\text {th }}$ & $75^{\text {th }}$ & $85^{\text {th }}$ & $90^{\text {th }}$ & $95^{\text {th }}$ \\
\hline Boys & & & & & & & & \\
14 & 1.24 & 1.43 & 1.76 & 2.14 & 2.52 & 2.73 & 2.88 & 3.09 \\
15 & 1.15 & 1.37 & 1.74 & 2.18 & 2.63 & 2.88 & 3.06 & 3.31 \\
16 & 1.10 & 1.29 & 1.65 & 2.09 & 2.57 & 2.84 & 3.03 & 3.32 \\
17 & 1.04 & 1.21 & 1.53 & 1.94 & 2.42 & 2.70 & 2.91 & 3.23 \\
18 & 0.98 & 1.13 & 1.41 & 1.78 & 2.22 & 2.49 & 2.69 & 3.00 \\
Girls & & & & & & & & \\
14 & 1.12 & 1.30 & 1.64 & 2.05 & 2.51 & 2.76 & 2.94 & 3.22 \\
15 & 1.24 & 1.46 & 1.82 & 2.24 & 2.68 & 2.92 & 3.09 & 3.34 \\
16 & 1.23 & 1.45 & 1.81 & 2.22 & 2.64 & 2.86 & 3.01 & 3.24 \\
17 & 1.18 & 1.39 & 1.75 & 2.16 & 2.57 & 2.80 & 2.95 & 3.19 \\
18 & 1.22 & 1.40 & 1.73 & 2.14 & 2.58 & 2.84 & 3.01 & 3.29 \\
\hline
\end{tabular}

\section{Statistical methods}

The data were first examined for outliers. The LMS method was used to obtain smoothed centile curves for each of the anthropometric variables. The need for centile curve arises when the measurement is strongly dependent on some covariate, often age, so that the reference range changes with the covariate. The LMS method uses BoxCox power transformation, which deals with the skewness present in the distribution of the anthropometric measurement and provides a way to normalize the measurement. The final centile curves are the result of smoothing three-age specific curves called L (lambda), M (mu) and S (sigma). The $\mathrm{M}$ and $\mathrm{S}$ curves correspond to the median and coefficient of variation of the measurement at each age whereas the L curve allows for the substantial age dependent skewness in the distribution of the measure-
Table 4: Smoothed age- and sex- specific percentile values for high-density lipoprotein cholesterol ( $\mathrm{mmol} / \mathrm{l})$ for urban Asian Indian adolescents 14-18 y of age.

\begin{tabular}{rllllllll}
\hline Age & $5^{\text {th }}$ & $10^{\text {th }}$ & $25^{\text {th }}$ & $50^{\text {th }}$ & $75^{\text {th }}$ & $85^{\text {th }}$ & $90^{\text {th }}$ & $95^{\text {th }}$ \\
\hline Boys & & & & & & & & \\
14 & 0.86 & 0.93 & 1.05 & 1.20 & 1.35 & 1.43 & 1.48 & 1.57 \\
15 & 0.91 & 0.98 & 1.10 & 1.23 & 1.36 & 1.43 & 1.48 & 1.55 \\
16 & 0.96 & 1.02 & 1.12 & 1.24 & 1.35 & 1.41 & 1.46 & 1.52 \\
17 & 0.98 & 1.04 & 1.13 & 1.24 & 1.36 & 1.42 & 1.47 & 1.54 \\
18 & 0.98 & 1.03 & 1.11 & 1.21 & 1.33 & 1.41 & 1.47 & 1.56 \\
Girls & & & & & & & & \\
14 & 0.86 & 0.93 & 1.07 & 1.24 & 1.41 & 1.51 & 1.58 & 1.68 \\
15 & 0.88 & 0.96 & 1.09 & 1.24 & 1.40 & 1.48 & 1.54 & 1.63 \\
16 & 0.90 & 0.97 & 1.10 & 1.24 & 1.38 & 1.46 & 1.52 & 1.60 \\
17 & 0.96 & 1.03 & 1.14 & 1.28 & 1.41 & 1.49 & 1.54 & 1.62 \\
18 & 1.12 & 1.19 & 1.30 & 1.43 & 1.57 & 1.64 & 1.70 & 1.77
\end{tabular}

ment. The points on each centile curves are defined by the following formula:

$\mathrm{M}(1+\mathrm{LSz})^{1 / \mathrm{L}}$,

where $\mathrm{L}, \mathrm{M}$ and $\mathrm{S}$ are the values of the fitted curves at each age, and $z$ denotes the $z$ score, i.e. the standard score with mean 0 and a standard deviation of 1 , for the required centile, for example $\mathrm{z}=1.645$ for the $95^{\text {th }}$ centile. The main assumption underlying the LMS method is that after Box-Cox power transformation the data at each age are normally distributed.

Descriptive statistics were computed using STATA 8.0 intercooled version (STATA Corporation, College Station Road, Houston, Texas) and the LMS regressions were performed using LMS Pro software (The Institute of Child Health, London).

\section{Results}

Smoothed age- and sex- specific cut-offs of serum TC, LDL-C, HDL-C, TG, non-HDL-C, SBP and DBP at the $5^{\text {th }}$, $10^{\text {th }}, 25^{\text {th }}, 50^{\text {th }}, 75^{\text {th }}, 85^{\text {th }}, 90^{\text {th }}$, and $95^{\text {th }}$ percentiles are presented in tables 2, 3, 4, 5, 6, 7, 8. Figures 1, 2, 3, 4, 5, 6,7 present the smoothed percentile curves graphically for boys and figures $8,9,10,11,12,13,14$ present the smoothed percentile curves graphically for girls.

Boys aged 14 to 16 y showed a minimal increase in mean serum TC followed by a sharp decline at ages 17 and $18 \mathrm{y}$. Serum TC in adolescent girls, on the other hand, showed a relative minimum at 16 and 17 y. Overall girls had higher mean TC than boys. The $95^{\text {th }}$ percentile for TC in girls aged $18 \mathrm{y}$ was the highest estimate for all ages and both sexes. Mean LDL-C in both boys and girls aged 14 to18 $\mathrm{y}$ was highest at $15 \mathrm{y}$ and decreased with age beyond 
Table 5: Smoothed age- and sex- specific percentile values for serum triglycerides ( $\mathrm{mmol} / \mathrm{l})$ for urban Asian Indian adolescents 14-18 y of age.

\begin{tabular}{cllllllll}
\hline Age $(y)$ & $5^{\text {th }}$ & $10^{\text {th }}$ & $25^{\text {th }}$ & $5^{\text {th }}$ & $75^{\text {th }}$ & $85^{\text {th }}$ & $90^{\text {th }}$ & $95^{\text {th }}$ \\
\hline Boys & & & & & & & & \\
14 & 0.55 & 0.62 & 0.75 & 0.95 & 1.22 & 1.40 & 1.54 & 1.79 \\
15 & 0.53 & 0.60 & 0.73 & 0.92 & 1.16 & 1.32 & 1.44 & 1.63 \\
16 & 0.54 & 0.61 & 0.76 & 0.95 & 1.20 & 1.35 & 1.46 & 1.65 \\
17 & 0.51 & 0.59 & 0.73 & 0.92 & 1.16 & 1.31 & 1.43 & 1.61 \\
18 & 0.54 & 0.60 & 0.74 & 0.94 & 1.19 & 1.36 & 1.49 & 1.71 \\
Girls & & & & & & & & \\
14 & 0.62 & 0.70 & 0.85 & 1.04 & 1.27 & 1.41 & 1.51 & 1.66 \\
15 & 0.60 & 0.68 & 0.82 & 1.00 & 1.22 & 1.35 & 1.45 & 1.60 \\
16 & 0.64 & 0.71 & 0.86 & 1.05 & 1.28 & 1.42 & 1.52 & 1.68 \\
17 & 0.60 & 0.67 & 0.82 & 1.01 & 1.23 & 1.37 & 1.47 & 1.62 \\
18 & 0.58 & 0.66 & 0.81 & 1.00 & 1.23 & 1.37 & 1.47 & 1.64
\end{tabular}

Table 6: Smoothed age- and sex- specific percentile values for non-HDL cholesterol ( $\mathrm{mmol} / \mathrm{l})$ for urban Asian Indian adolescents 14-18 y of age.

\begin{tabular}{ccccccccc}
\hline Age $(y)$ & $5^{\text {th }}$ & $10^{\text {th }}$ & $25^{\text {th }}$ & $50^{\text {th }}$ & $75^{\text {th }}$ & $85^{\text {th }}$ & $90^{\text {th }}$ & $95^{\text {th }}$ \\
\hline Boys & & & & & & & & \\
14 & 1.71 & 1.91 & 2.24 & 2.62 & 3.01 & 3.23 & 3.38 & 3.60 \\
15 & 1.60 & 1.81 & 2.19 & 2.63 & 3.08 & 3.34 & 3.52 & 3.78 \\
16 & 1.56 & 1.76 & 2.13 & 2.57 & 3.05 & 3.33 & 3.52 & 3.82 \\
17 & 1.46 & 1.63 & 1.95 & 2.36 & 2.83 & 3.12 & 3.32 & 3.64 \\
18 & 1.42 & 1.56 & 1.85 & 2.22 & 2.68 & 2.97 & 3.19 & 3.53 \\
Girls & & & & & & & & \\
14 & 1.66 & 1.84 & 2.17 & 2.56 & 2.98 & 3.23 & 3.40 & 3.65 \\
15 & 1.79 & 1.99 & 2.35 & 2.75 & 3.17 & 3.40 & 3.56 & 3.80 \\
16 & 1.77 & 1.98 & 2.33 & 2.73 & 3.13 & 3.35 & 3.50 & 3.72 \\
17 & 1.70 & 1.90 & 2.25 & 2.64 & 3.06 & 3.28 & 3.44 & 3.67 \\
18 & 1.67 & 1.86 & 2.20 & 2.61 & 3.06 & 3.32 & 3.50 & 3.78 \\
\hline
\end{tabular}

15 y. Girls had higher mean LDL-C than boys at all ages. The serum non-HDL-C levels followed a similar trend. The $95^{\text {th }}$ and $75^{\text {th }}$ percentile of TC and LDL-C (which define high and borderline elevated cholesterol respectively in children and adolescents) are of special note [18]. Mean HDL-C was relatively constant among 14 to $18 \mathrm{y}$ old boys and girls except that in girls mean HDL$\mathrm{C}$ levels increased $1.5 \mathrm{mmol} / \mathrm{l}$ from 17 to $18 \mathrm{y}$. The $5^{\text {th }}$ percentile, which would define low HDL-C in these adolescents, is also represented in table 4. Mean serum TG levels did not vary significantly among 15 to 18 year olds except for a small increase at 16 years for both sexes. The mean TG was generally higher in girls at all ages.

The mean SBP and DBP in both sexes did not vary significantly between the different age groups. Boys aged 16 to 18 y had a greater systolic and diastolic BP than girls.
Table 7: Smoothed age- and sex- specific percentile values for systolic blood pressure $(\mathrm{mm} \mathbf{H g})$ for urban Asian Indian adolescents I4-18 y of age.

\begin{tabular}{ccccccccc}
\hline Age $(y)$ & $5^{\text {th }}$ & $10^{\text {th }}$ & $25^{\text {th }}$ & $50^{\text {th }}$ & $75^{\text {th }}$ & $85^{\text {th }}$ & $90^{\text {th }}$ & $95^{\text {th }}$ \\
\hline Boys & & & & & & & & \\
14 & 99 & 103 & 108 & 115 & 121 & 125 & 127 & 131 \\
15 & 98 & 101 & 107 & 113 & 119 & 123 & 125 & 128 \\
16 & 98 & 102 & 108 & 114 & 120 & 123 & 125 & 129 \\
17 & 100 & 103 & 109 & 115 & 121 & 125 & 127 & 130 \\
18 & 102 & 105 & 110 & 116 & 122 & 125 & 128 & 131 \\
Girls & & & & & & & & \\
14 & 96 & 100 & 105 & 112 & 118 & 121 & 123 & 127 \\
15 & 97 & 100 & 105 & 111 & 118 & 121 & 123 & 127 \\
16 & 97 & 100 & 105 & 111 & 118 & 121 & 124 & 127 \\
17 & 95 & 98 & 103 & 109 & 116 & 119 & 121 & 125 \\
18 & 96 & 99 & 104 & 110 & 116 & 119 & 121 & 124
\end{tabular}

Table 8: Smoothed age- and sex- specific percentile values for diastolic blood pressure $(\mathrm{mm} \mathrm{Hg})$ for urban Asian Indian adolescents 14-18 y of age.

\begin{tabular}{ccccccccc}
\hline Age $(y)$ & $5^{\text {th }}$ & $10^{\text {th }}$ & $25^{\text {th }}$ & $50^{\text {th }}$ & $75^{\text {th }}$ & $85^{\text {th }}$ & $90^{\text {th }}$ & $95^{\text {th }}$ \\
\hline Boys & & & & & & & & \\
14 & 61 & 64 & 68 & 73 & 78 & 81 & 82 & 85 \\
15 & 62 & 64 & 69 & 74 & 79 & 81 & 83 & 85 \\
16 & 62 & 65 & 69 & 74 & 78 & 81 & 82 & 85 \\
17 & 64 & 67 & 71 & 75 & 80 & 82 & 84 & 86 \\
18 & 64 & 67 & 71 & 76 & 80 & 82 & 84 & 86 \\
Girls & & & & & & & & \\
14 & 60 & 63 & 68 & 72 & 77 & 79 & 81 & 83 \\
15 & 62 & 64 & 69 & 73 & 78 & 80 & 82 & 84 \\
16 & 62 & 64 & 68 & 73 & 77 & 80 & 81 & 84 \\
17 & 60 & 63 & 67 & 71 & 76 & 78 & 80 & 83 \\
18 & 61 & 63 & 68 & 72 & 77 & 80 & 82 & 85 \\
\hline
\end{tabular}

\section{Discussion}

Representative age- and sex- specific reference data on the distribution of lipids and blood pressure in urban Asian Indian adolescents aged 14 to $18 \mathrm{y}$ have been provided for the first time. This data can be used as a reference for the urban Indian population for comparison to other studies, to measure the progress in health of Indian adolescents in the future, and to plan and implement intervention programs for the prevention of cardiovascular disease.

There are interesting trends in the TC and HDL-C levels in urban Indian adolescent population, which may be significantly accounted for by the marked diet and lifestyle changes in the 15 to $18 \mathrm{y}$ age group. 15 to $17 \mathrm{y}$ old adolescents in India are subjected to strenuous and important examinations leading to adverse diet changes 


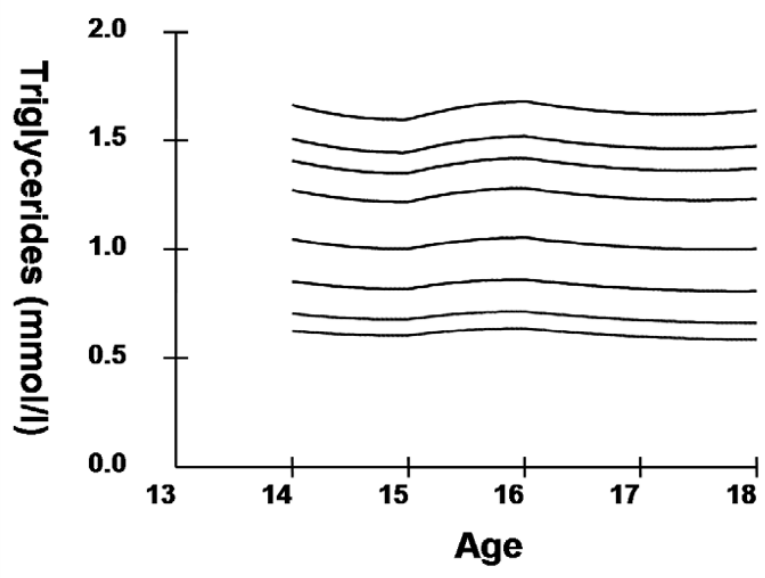

Figure 9

Smoothed percentile curves for the $5^{\text {th }}, 10^{\text {th }}, 25^{\text {th }}, 50^{\text {th }}, 75^{\text {th }}$, $85^{\text {th }}, 90^{\text {th }}$ and $95^{\text {th }}$ percentiles of serum triglycerides for urban girls 14-18 years of age.

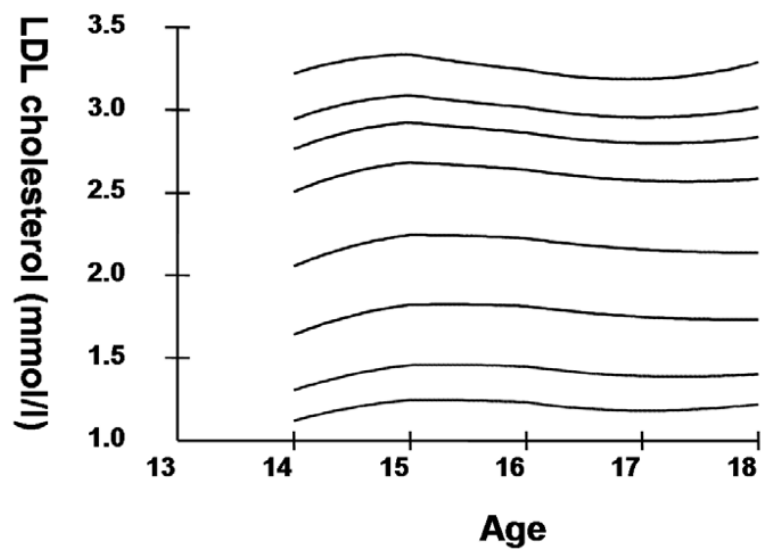

Figure 10

Smoothed percentile curves for the $5^{\text {th }}, 10^{\text {th }}, 25^{\text {th }}, 50^{\text {th }}, 75^{\text {th }}$, $85^{\text {th }}, 90^{\text {th }}$ and $95^{\text {th }}$ percentiles of low-density lipoprotein cholesterol for urban girls 14-18 years of age.

and inactivity during this period [19], which may have resulted in high TC and lower HDL-C levels in these adolescents. An average urban Indian adolescent enters college at the age of 17 to $18 \mathrm{y}$, when physical activity and diet are likely to improve which could lead to lower TC and higher HDL-C levels observed in this age group.

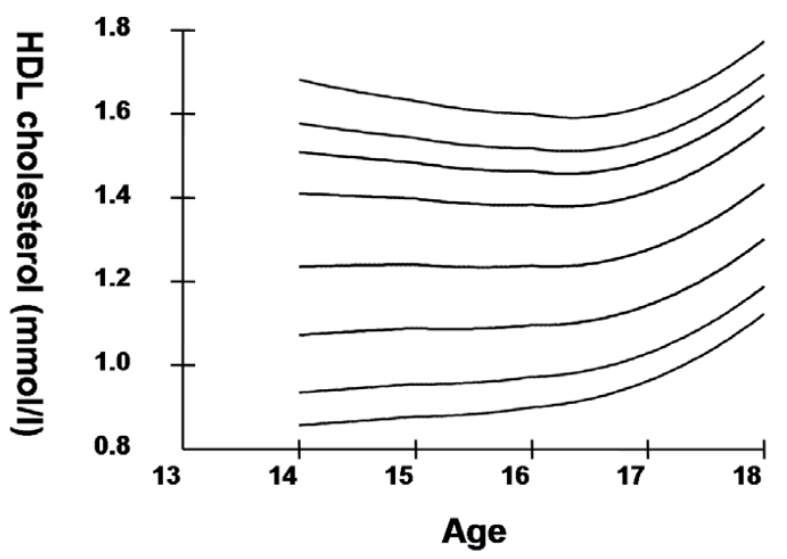

Figure I I

Smoothed percentile curves for the $5^{\text {th }}, 10^{\text {th }}, 25^{\text {th }}, 50^{\text {th }}, 75^{\text {th }}$, $85^{\text {th }}, 90^{\text {th }}$ and $95^{\text {th }}$ percentiles of high-density lipoprotein cholesterol for urban girls 14-18 years of age.

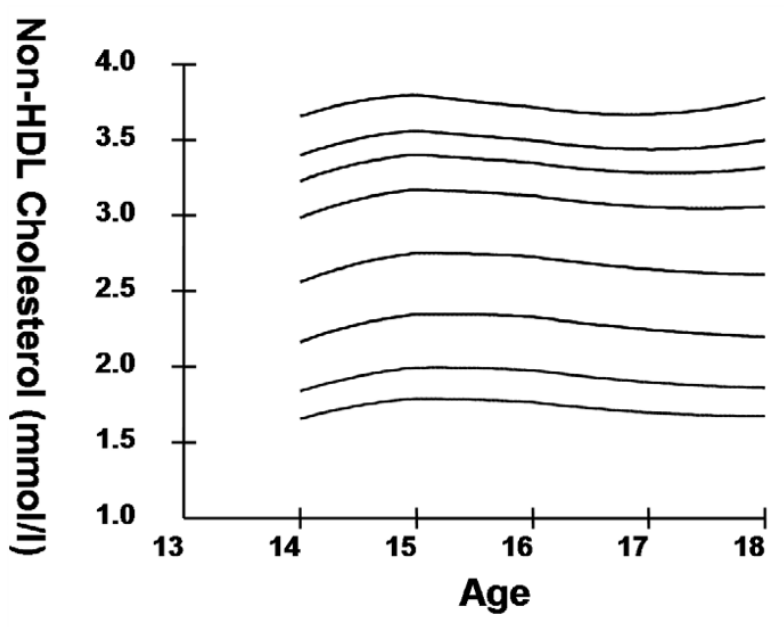

Figure 12

Smoothed percentile curves for the $5^{\text {th }}, 10^{\text {th }}, 25^{\text {th }}, 50^{\text {th }}, 75^{\text {th }}$, $85^{\text {th }}, 90^{\text {th }}$ and $95^{\text {th }}$ percentiles of non high-density lipoprotein cholesterol for urban girls 14-18 years of age.

The serum lipid levels were compared with Lipid Research Clinics (LRC) and NHANES III data from the USA [2022]. TC and LDL-C levels were consistently lower in Asian Indians than in the USA in both sexes and across the age groups studied. Secular data in TC levels in adolescents in the USA, showed a downward trend from 1966-1970 (NHES III) to 1988-1994 (NHANES III) [22]. However, 


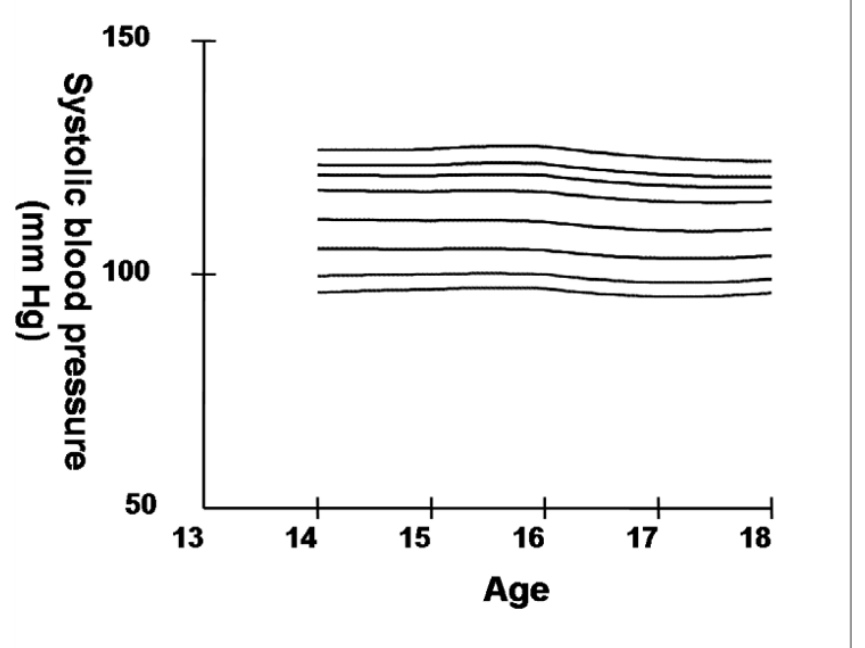

\section{Figure I 3}

Smoothed percentile curves for the $5^{\text {th }}, 10^{\text {th }}, 25^{\text {th }}, 50^{\text {th }}, 75^{\text {th }}$, $85^{\text {th }}, 90^{\text {th }}$ and $95^{\text {th }}$ percentiles of systolic blood pressure for urban girls 14-18 years of age.

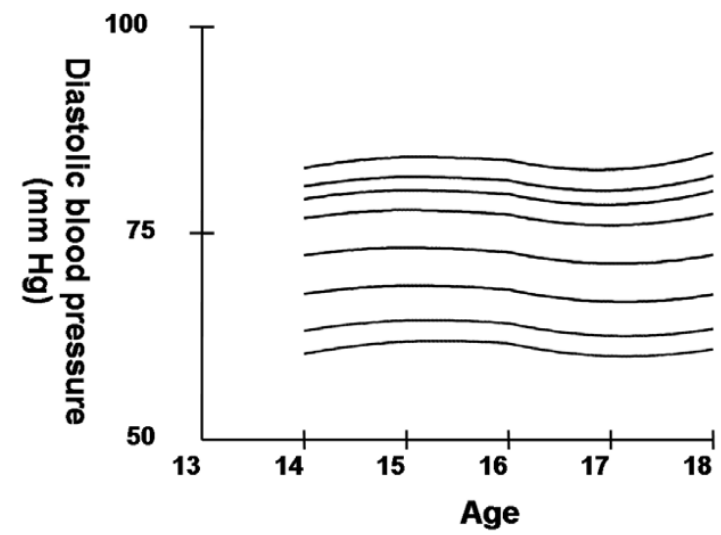

\section{Figure 14}

Smoothed percentile curves for the $5^{\text {th }}, 10^{\text {th }}, 25^{\text {th }}, 50^{\text {th }}, 75^{\text {th }}$, $85^{\text {th }}, 90^{\text {th }}$ and $95^{\text {th }}$ percentiles of diastolic blood pressure for urban girls 14-18 years of age.

TC levels in Asian Indian adolescents were lower than those observed in the USA in the more recent NHANES III data.

The data show that TG levels in Asian Indian adolescents were lower than that observed in the NHANES III study at percentiles higher than the $75^{\text {th }}$, despite being higher at the lower percentiles [22]. Asian Indian adolescents had higher HDL-C levels at lower percentiles than their counterparts in the USA [22] and lower HDL-C levels at percentiles greater than the $50^{\text {th }}$. Although the TC and LDL-C levels are lower in urban Asian Indian adolescents than in other populations, however, the fasting hyperinsulinemia (fasting serum insulin level $>20$ microunits $/ \mathrm{ml}$ )[23], indicative of insulin resistance, was seen in $50 \%$ of girls and $19 \%$ of boys, in addition to the presence of other cardiovascular risk factors such as high C-reactive protein (CRP) levels $[13,14,16]$. These data indicate that although lipids may be important in pathogenesis of $\mathrm{CAD}$ in adult Asian Indians, it may not be always possible to ascertain the risk based on lipid levels alone during childhood. The cardiovascular risk in young Asian Indians could be better estimated by assessing several other biochemical factors (insulin, CRP, nonesterified fatty acids) in addition to lipids.

\section{Conflict of Interest}

The author(s) declare that they have no competing interests.

\section{Acknowledgements}

We thank Dr. Tim J Cole of The Institute of Child Health, London, for providing the LMS program and for useful suggestions. The study was funded by a grant from the Department of Science and Technology, Ministry of Science and Technology, Government of India, New Delhi. The authors are thankful to Ministry of Education, Government of New Delhi for their assistance in conducting the study. The cooperation of the children who took part in the study, and the help extended by the principals, teachers, and staff of the various schools and colleges where the study was conducted is greatly appreciated.

\section{References}

I. Misra A: Risk factors for atherosclerosis in young individuals. J Cardiovasc Risk 2000, 7:2 I5-229.

2. Strong JP: The natural history of atherosclerosis in childhood. Ann N Y Acad Sci 1991, 623:9-15.

3. McGill HCJ, McMahan CA, Malcom GT, Oalmann MC, Strong JP: Effects of serum lipoproteins and smoking on atherosclerosis in young men and women. The PDAY Research Group. Pathobiological Determinants of Atherosclerosis in Youth. Arterioscler Thromb Vasc Biol 1997, 17:95-106.

4. McGill HCJ, McMahan CA: Determinants of atherosclerosis in the young. Pathobiological Determinants of Atherosclerosis in Youth (PDAY) Research Group. Am J Cardiol 1998, 82:30T-36T.

5. Executive Summary of the Third Report of the National Cholesterol Education Program (NCEP) Expert Panel on Detection, Evaluation, and Treatment of High Blood Cholesterol in Adults (Adult Treatment Panel III). JAMA 200I, 285:2486-2497.

6. Austin MA, Hokanson JE, Edwards KL: Hypertriglyceridemia as a cardiovascular risk factor. Am / Cardiol 1998, 81:7B-12B.

7. Assmann $G$, Schulte $H$, Funke $H$, von Eckardstein $A$ : The emergence of triglycerides as a significant independent risk factor in coronary artery disease. Eur Heart ] 1998, 19 Suppl M:M8- 14.

8. Grundy SM: Hypertriglyceridemia, atherogenic dyslipidemia, and the metabolic syndrome. Am J Cardiol 1998, 81 : I 8B-25B.

9. Gordon DJ, Probstfield JL, Garrison RJ, Neaton JD, Castelli WP, Knoke JD, Jacobs DRJ, Bangdiwala S, Tyroler HA: High-density lipoprotein cholesterol and cardiovascular disease. Four prospective American studies. Circulation 1989, 79:8-15. 
10. Cui $Y$, Blumenthal RS, Flaws JA, Whiteman MK, Langenberg $P$, Bachorik PS, Bush TL: Non-high-density lipoprotein cholesterol level as a predictor of cardiovascular disease mortality. Arch Intern Med 200I, 16I:I4I3-14I9.

II. Reddy KS, Yusuf S: Emerging epidemic of cardiovascular disease in developing countries. Circulation 1998, 97:596-60I.

12. Misra A, Vikram NK: Insulin resistance syndrome (metabolic syndrome) and obesity in Asian Indians: evidence and implications. Nutrition 2004, 20:482-49I.

13. Misra A, Vikram NK, Arya S, Pandey RM, Dhingra V, Chatterjee A Dwivedi M, Sharma R, Luthra K, Guleria R, Talwar KK: High prevalence of insulin resistance in postpubertal Asian Indian children is associated with adverse truncal body fat patterning abdominal adiposity and excess body fat. Int J Obes Relat Metab Disord 2004, 28: I 2I 7- 1226.

14. Vikram NK, Misra A, Pandey RM, Dwivedi M, Luthra K: Adiponectin levels in postpubertal asian Indian adolescents: Relationships with insulin resistance and C-reactive protein. Metabolism 2004, 53:1336-|34|.

15. Lemeshow S, Stroh G: Sampling techniques for evaluating health parameters in developing countries. National Academy Press, Washington, DC 1988.

16. Vikram NK, Misra A, Dwivedi M, Sharma R, Pandey RM, Luthra K Chatterjee A, Dhingra V, Jailkhani BL, Talwar KK, Guleria R: Correlations of C-reactive protein levels with anthropometric profile, percentage of body fat and lipids in healthy adolescents and young adults in urban North India. Atherosclerosis 2003, 168:305-313.

17. Friedewald WT, Levy RI, Fredrikson DS: Estimation of the concentration of low-density lipoprotein cholesterol in plasma without use of the preparative ultracentrifuge. Clin Chem 1972, I 8:499-502.

18. National Cholesterol Education Program (NCEP): highlights of the report of the Expert Panel on Blood Cholesterol Levels in Children and Adolescents. Pediatrics 1992, 89:495-50।.

19. Dhingra V, Chatterjee A, Guleria R, Sharma R, Pandey RM, Talwar KK, Misra A: Adverse physical activity pattern in urban adolescents. J Assoc Physicians India 2002, 50:I52I.

20. American Academy of Pediatrics. National Cholesterol Education Program: Report of the Expert Panel on Blood Cholesterol Levels in Children and Adolescents. Pediatrics 1992, 89:525-584.

21. Plasma lipid distributions in selected North American populations: the Lipid Research Clinics Program Prevalence Study. The Lipid Research Clinics Program Epidemiology Committee. Circulation 1979, 60:427-439.

22. Hickman TB, Briefel RR, Carroll MD, Rifkind BM, Cleeman Jl, Maurer $K R$, Johnson CL: Distributions and trends of serum lipid levels among United States children and adolescents ages 4-19 years: data from the Third National Health and Nutrition Examination Survey. Prev Med 1998, 27:879-890.

23. Alberti KG, Zimmet PZ: Definition, diagnosis and classification of diabetes mellitus and its complications. Part I: diagnosis and classification of diabetes mellitus provisional report of a WHO consultation. Diabet Med 1998, I5:539-553.
Publish with Biomed Central and every scientist can read your work free of charge

"BioMed Central will be the most significant development for disseminating the results of biomedical research in our lifetime. "

Sir Paul Nurse, Cancer Research UK

Your research papers will be:

- available free of charge to the entire biomedical community

- peer reviewed and published immediately upon acceptance

- cited in PubMed and archived on PubMed Central

- yours - you keep the copyright
BioMedcentral 